DOI: 10.34015/2523-4552.2021.3.03

УДК 343.341+343.237:343.974

Вознюк А. А., доктор юридичних наук, професор, завідувач наукової лабораторії з проблем протидії злочинності навчально-наукового інституту № 1 Національної академії внутрішніх справ

ORCID: 0000-0002-3352-5626

\title{
ВСТАНОВЛЕННЯ АБО ПОШИРЕННЯ ЗЛОЧИННОГО ВПЛИВУ: АКТУАЛЬНІ ПИТАННЯ КРИМІНАЛЬНОЇ ВІДПОВІДАЛЬНОСТІ
}

У статті аналізуються актуальні проблеми, пов'язані з криміналізацією встановлення або поширення злочинного впливу у ст. 255-1 Кримінального кодексу України. Досліджено доцільність криміналізації злочинного впливу, розкрито його поняття, ознаки та концептуальні вади, визначено суспільну небезпеку злочину, передбаченого у ст. 255-1 Кримінального кодексу України, висвітлено питання про об'єкт, об'єктивну сторону, суб'єкта та кваліфікуючі й особливо кваліфікуючі ознаки цього злочину.

Виявлено суттєві вади, що перешкоджають ефективному застосуванню ст. 255-1 Кримінального кодексу України на практиці, та надано пропозиції щодо їх усунення. Сформульовано рекомендації щодо кваліфікації встановлення або поширення злочинного впливу.

Ключові слова: організована злочинність; організована група; злочинна організація; злочинна спільнота; співучасть; злочинна діяльність; криміналізація; злочинний вплив; «вор в законі».

В статье анализируются актуальные проблемы, связанные с криминализацией установления или распространения преступного воздействия в ст. 255-1 Уголовного кодекса Украины. Исследована целесообразность криминализации преступного воздействия, раскрыто его понятие, признаки и концептуальные изъяны, определена общественная опасность преступления, предусмотренного ст. 255-1 Уголовного кодекса Украины, освещены вопросы об объекте, объективной стороне, субъекте, квалифицирующих и особо квалифицирующих признаках этого преступления.

Выявлены существенные изъяны, препятствующие эффективному применению ст. 255-1 Уголовного кодекса Украины на практике и предоставлены предложения по их устранению. Сформулированы рекомендации по квалификации установления или распространения преступного воздействия.

Ключевые слова: организованная преступность; организованная группа; преступная организация; преступное сообщество; соучастие; преступная деятельность; криминализация; преступное воздействие; «вор в законе». 
Постановка проблеми. Організована злочинність несла, несе i ймовірно в найближчому майбутньому буде нести серйозну загрозу правам і свободам громадян в усьому світі, не оминаючи найбільш розвинених держав (Італію, Китай, Німеччину, США, Туреччину, Японію тощо). Не $є$ виключенням й Україна, в якій організована злочинність $\epsilon$ поширеним явищем.

«Організована злочинність ${ }^{1}$, а також особи, які здійснюють їі організацію та керівництво, - «злодії у законі», формують в Україні типове для держав колишнього СРСР злочинне середовище. Воно характеризується наявністю жорсткого кодексу поведінки, сталих кримінальних традицій, високим рівнем організованості, ієрархічності, закритості і конспіративності» [1]. «Організовані злочинні об'єднання в умовах розповсюдження корупції ${ }^{2}$ поширюють сферу своїх інтересів, проникають в органи влади як на місцевому, регіональному, так і загальнодержавному рівні, встановлюють «наглядачів», а інколи навіть підміняють окремі функції держави та місцевого самоврядування» [9, c. 21]. Не випадково корупцію вважають складовою організованої злочинності [10], а наявність корупційних зв'язків - $\dddot{1 і ̈ ~ к о н с т и т у т и в н о ю ~}$ ознакою $[11$, с. 54]. Особливо небезпечною формою корупції називають ту, яка здійснюється організованою злочинністю [12]. Корупцію визнають необхідною практикою для продовження діяльності будь-якої організованої злочинної групи [13].

Нині на теренах України організована злочинність функціонує у різних формах, однією 3 яких $\epsilon$ злодійська спільнота, що поєднує в собі елементи не лише організованої, але й професійної та рецидивної кримінально протиправної діяльності, характеризується певними правилами та традиціями, а також розгалуженою інфраструктурою, зокрема тісними зв'язками 3 представниками не лише вітчизняного злодійського світу, а й організованого криміналітету за кордоном. Як слушно зауважують вчені, в Україні сформувалося специфічне злочинне середовище, що протиставляється владі, законам і культурі законослухняного суспільства. В окремих регіонах країни сформувалася ціла система неправових взаємозв'язків і відносин, що здатні конкурувати 3 легальними інституціями соціуму. Характерними особливостями сучасного кримінального світу є те, що він має власну економіку, ідеологію, неписані, але беззаперечно виконувані, жорстокі й невідворотні «закони кримінального світу», свою охоронну систему й навіть механізми «соціального захисту» від будь-якого втручання ззовні $[14$, с. $175-176]$.

13 огляду на трансформацію у КК України злочинів у кримінальні правопорушення, 3 поділом останніх на злочини та кримінальні проступки, окрім терміну «організована злочинність» ймовірно можна вживати інший термін - «організована кримінально протиправна діяльність». Така діяльність більш точно характеризує це суспільно небезпечне явище, оскільки учасники організованих злочинних об'єднань вчиняють не лише злочини, але й кримінальні проступки.

2 На високий рівень корупції в Україні та проникнення ії в різні сфери життя суспільства неодноразово звертали увагу вчені [2-8]. 
Злодійська спільнота - це одна 3 найбільш небезпечних проявів кримінально протиправної діяльності, оскільки нейтралізація окремих їі учасників та їх об'єднань не призводить до ліквідації цього соціально небезпечного явища. Вона має здатність до самовідтворення (на зміну одному кримінальному авторитету, приходить інший). Злодійську спільноту на теренах України та інших країн-вихідців 3 СРСР можна вважати найвідомішою національною формою організованої злочинності на кшталт Якудзи в Японії, мафії - в Америці, Італії, Канаді, Тріад - в Китаї, Гонконзі та Тайвані, картелей - в Колумбії тощо.

Представники сучасного організованого криміналітету в Україні, 3 одного боку, постійно удосконалюють форми та методи кримінально протиправної діяльності, опановують нові технологї кримінально протиправної діяльності $^{1}$, a, 3 другого, продовжують дотримуватися встановлених правил, звичаїв, традицій, характерних для злочинної спільноти країнвихідців з СРСР. Упродовж 2015-2019 років вони суттєво посилили свої позиції, в умовах перманентного реформування правоохоронних органів (насамперед 3 огляду на ліквідацію ГУБ03) та суттєвого зростання рівня корупції в державі. Окрім того, введення до КК Вірменії, Грузії, Росії нових та особливих підстав кримінальної відповідальності злочинних авторитетів, насамперед «злодіїв в законі», зумовило часткову «міграцію» цих суб’єктів підвищеного зло- чинного впливу із зазначених країн на території інших держав, зокрема i в Україну.

За таких обставин важливим кроком стало схвалення Кабінетом Міністрів України Стратегії боротьби 3 організованою злочинністю від 16 вересня 2020 р. та створення нових кримінально-правових інструментів у протидії організованій злочинності, які закріплено у Законі України «Про внесення змін до деяких законодавчих актів України щодо відповідальності за злочини, вчинені злочинною спільнотою» від 4 червня 2020 р. Cеред нововведень слід звернути увагу на криміналізацію встановлення або поширення злочинного впливу (ст. 255-1 КК України), оскільки це абсолютно нова для вітчизняного КК України кримінально-правова заборона, зорієнтована на кримінальних авторитетів. Відтак виникла необхідність у виробленні рекомендацій щодо іï тлумачення, подальшого застосування та удосконалення.

Постановка завдання. Завданням статті $€$ аналіз актуальних питань кримінальної відповідальності за встановлення або поширення злочинного впливу. Це дасть змогу оцінити позитивні та негативні сторони кримінально-правової заборони, передбаченої ст.255-1 КК України, розкрити іï зміст та сформулювати рекомендації щодо застосування та подальшого вдосконалення.

Виклад основного матеріалу.

1. Необхідність криміналізації злочинного впливу.

Чинне законодавство України тривалий час містило низку право[15-17].

${ }^{1}$ Наприклад, технології рейдерства, кіберзлочинів, використання електронних грошей 
вих механізмів боротьби з організованою злочинністю, які в цілому відповідали загальносвітовій практиці. Однак їх було недостатньо для ефективного кримінально-правового впливу на певні категорії представників організованої злочинності йдеться насамперед про кримінальних авторитетів - «злодіїв в законі», «смотрящих», «положенців». Чому недостатньо? Кожного із зазначених суб'єктів можна притягнути до кримінальної відповідальності за вчинення певного злочину (розбою, вимагання, викрадення людини тощо). Це і відбувається в частині випадків на практиці. У подальшому, здобуваючи відповідний досвід, вказані особи вживають низку заходів щодо уникнення кримінальної відповідальності, зокрема шляхом конспірації своєї кримінально протиправної діяльності, підкупу правоохоронців та суддів, застосування заходів впливу на потерпілих та свідків. Частині кримінальних авторитетів вдається здобути високий статус у кримінальній ієрархії - стати «злодієм в законі», «положенцем», «смотрящим». За таких обставин їх суспільно небезпечна поведінка зазнає певної трансформації: відбувається частковий перехід від участі в окремих злочинах і кримінальних проступках в ролі організаторів, підбурювачів, пособників, виконавців чи співвиконавців до координації кримінально протиправної діяльності на певній території, сприяння ій, спонукання до неї. Акцент суспільно небезпечних діянь кримінальних авторитетів зміщується від участі в окремих злочинах і кримінальних проступках до незаконного впливу на кримінально протиправну діяльність в цілому. Відтак притягнути до кримінальної відповідальності цих осіб стає дедалі складніше, а у певних випадках взагалі неможливо (коли вони не вчиняють певні злочини, або вчиняють, однак їх неможливо задокументувати чи довести в суді). В основі «філософії» чинного КК України індивідуальне кримінальне правопорушення, яке може бути вчинене як самостійно, так і у співучасті. Тому, наприклад, «злодія в законі» чи іншого кримінального авторитета неможливо було притягнути до кримінальної відповідальності за вирішення спорів (суперечок), які виникають між особами 3 погляду неписаних злодійських «законів», «за поняттями» (тобто системою неформальних норм і правил, які діють у злочинному середовищі), коли він виступав в ролі «мирового судді», та визначав обгрунтованість претензій, а також ухвалював рішення про покарання винуватців тощо. Звісно, якщо в його діях не було складу іншого кримінального правопорушення (вимагання, примушування до виконання чи невиконання цивільно-правових зобов'язань тощо). Не було підстав притягнути його до кримінальної відповідальності і за координацію кримінально протиправної діяльності на певній території (наприклад, надання дозволу індивідуальним суб'єктам та злочинним об'єднанням вчиняти кримінальні правопорушення) та сприяння їй (наприклад, шляхом утримання та забезпечення наповнення «общака»). Слід наголосити, що під час координації кримінально протиправної діяльності кримінальні авторитети можуть навіть не знати хто, коли, де, в який спосіб і щодо кого вчинить кримінальний просту- 
пок чи злочин, що фактично унеможливлює притягнення їх до відповідальності як співучасників того чи іншого кримінального правопорушення.

Тому важливим кроком держави стала реанімація ГУБОЗ в особі ДСР НП України, а також надання цьому суб'єкту відповідних кримінально-правових інструментів у формі нових підстав кримінальної відповідальності кримінальних авторитетів, їх пособників та осіб, які звертаються до них 3 приводу розв'язання певних проблем: КК України доповнено ст. 255-1, яка передбачає підстави кримінальної відповідальності за умисне встановлення або поширення в суспільстві злочинного впливу за відсутності ознак, зазначених у ч. 5 ст. 255 КК України, а також ст. 255-2, що встановлює кримінально-правову заборону на звернення за застосуванням злочинного впливу.

Криміналізація злочинного впливу - це створення нової «філософії» протидії кримінальним авторитетам із злодійського середовища. Особливість цього інструменту в тому, що він стосується діянь, пов'язаних не з певним злочином, а 3 кримінально протиправною діяльністю і таким чином усуває низку прогалин у підставах притягнення до кримінальної відповідальності найбільш небезпечних представників організованої злочинності. Криміналізація злочинного впливу надає можливість притягнути до відповідальності кримінального авторитета за сприяння та координацію злочинної діяльності, особливо у тих випадках, коли неможливо довести співучасть такого суб'єкта в індивідуальних злочинах.
Водночас не слід ідеалізувати нові кримінально-правові заборони у протидії організованій злочинності, оскільки вчені доводять, що спільнота «ворів в законі» може пристосовуватися до мінливого середовища. Навіть найжорсткіших державних репресій недостатньо для ліквідації мафії. Муссоліні не вдалося знищити сицилійську мафію як Сталін не зміг ліквідувати «ворів в законі». Ефективна політика проти мафії має виходити за межі репресій та стосуватися усунення соціальних й економічних причин існування таких організацій [18]. Адже поява злочинних організацій пояснюється неспроможністю слабких держав забезпечити безпеку своїх громадян та надати їм необхідні послуги. Це надає можливості злочинним об'єднанням для заміни важливих функцій держав [19].

\section{2. Злочинний вплив: понят-} тя, ознаки, концептуальні вади.

У примітці 1 до ст. 255-1 КК України під злочинним впливом пропонується розуміти будь-які дії особи, яка завдяки авторитету, іншим особистим якостям чи можливостям, сприяє (створює умови), спонукає, координує або здійснює інший вплив на злочинну діяльність, організовує або безпосередньо здійснює розподіл коштів, майна чи інших активів (доходів від них), спрямованих на забезпечення такої діяльності.

Якщо застосувати правила буквального та граматичного тлумачення кримінально-правових норм, під злочинним впливом очевидно слід розуміти будь-які діі певного суб'єкта. Таким суб'єктом визнається особа, яка завдяки авторитету, іншим особистим якостям чи можли- 
востям, сприяє (створює умови), спонукає, координує або здійснює інший вплив на злочинну діяльність, організовує або безпосередньо здійснює розподіл коштів, майна чи інших активів (доходів від них), спрямованих на забезпечення такої діяльності. Відтак, слід ще раз підкреслити, що виходячи з редакції статті відповідальність має наставати не за сприяння злочинній діяльності чи інший вплив на злочинну діяльність, а будь-які дії. Будь-які дії очевидно можуть бути як правомірними, так i протиправними.

На цю проблему звернули увагу й інші дослідники. А. О. Нікітін вважає, що визначення злочинного впливу, подане у примітці до нової редакції ст. 255 КК України, є настільки широким, що фактично визнати злочинним впливом можна майже будь-які дії особи $[20$, с. 169]. К. В. Юртаєва, Р. Р. Романів називають суттєвим недоліком кримінального законодавства в частині відповідальності за злочини, вчинені злочинною спільнотою, невдалу спробу надати визначення терміну «злочинний вплив». Під злочинним впливом законодавець розуміє не самі дії, спрямовані на організацію або координацію злочинної діяльності, а будь-які дії особи, яка має зазначені в законі якості. При чому згідно буквального тлумачення положення закону самі дії можуть бути й не суспільно небезпечними. Це повністю підриває вимогу до визначеності кримінально-правових норм, i, фактично, призводить до об'єктивного ставлення в вину [21, с. 226-227].

У зв'язку з цим О. І. Міневич наголошує, що якщо законодавець визнає злочинними дії невизначеного характеру й змісту, то, по суті, потенційно кримінальною можна вважати будь-яку поведінку чи життєву позицію людини [22, с. 124]. В цьому контексті П.Фріс та І.Фріс зауважили, що можна передбачити можливість притягнення до кримінальної відповідальності сценаристів, режисерів й акторів кінофільмів де зображуються сцени з життя злочинців, авторів художніх творів та таке інше. Хоча сама постановка такого питання вже абсурдна, однак із великою долею вірогідності можна (з часом) передбачити появу кримінальних проваджень із притягненням до відповідальності зазначених осіб [23]. На думку ж В. Речицького, якщо будь-яку особу КК України може звинувачувати у «злочинному впливові», а суд може покарати її суворим вироком лише на тій підставі, що вона здійснювала конкретно не визначений в законі («будь-які дії») будь-який («інший») вплив на будь-яку злочинну діяльність необмеженої кількості осіб, то цього достатньо, щоб визнати такий підхід неконституційним. Адже саме в ньому рельєфно проявляється рецидив домінування держави над громадянином, несподіване відродження прикрих ознак тоталітаризмy [24].

Цим не обмежуються вади дефініції злочинного впливу. Використання таких словосполучень, як «будь-які дії», «інші якості чи можливості», «інший вплив на злочинну діяльність», на переконання А. О. Нікітіна, узагалі нівелює запропоноване визначення поняття «злочинний вплив» і створює для правоохоронних органів широке поле для можливих зловживань [20, с. 169]. К. В. Юртаєва, Р. Р. Романів вважають, що розпливчастість понять автори- 
тет, інші особисті якості чи можливості, завдяки яким особа має вплив на злочину спільноту, може призвести до судового свавілля під час застосування цієї норми $[21$, с. $226-$ 227]. О. І. Міневич також слушно констатує наявність оціночного судження «завдяки авторитету, іншим особистим якостям чи можливостям», котре можна тлумачити надзвичайно широко [22, с. 122].

Дійсно, у визначенні злочинного впливу присутня вказівка на те, що особа вчиняє певні дії завдяки авторитету, іншим особистим якостям чи можливостям. У зв'язку 3 цим виникає питання: а які ще $\epsilon$ варіанти і чи потрібна ця ознака? Щодо авторитету та особистих якостей більш- менш усе зрозуміло (особа дає вказівки, їх виконують, оскільки поважають, бояться тощо). Натомість можливості включають дуже широке коло умов, завдяки яким відповідний суб'єкт може здійснювати злочинний вплив. Практично будь-яка особа за власною ініціативою може надати певну допомогу злочинному об'єднанню (інформацією, грошима, знаряддями і засобами тощо). Виходить, що будьяка особа, якщо хоче, то може сприяти злочинній діяльності якщо не авторитетом чи особистими якостями, то завдяки наявним можливостям. Тоді навіщо це додаткове навантаження на предмет доказування? [25, с. 183].

Тому цілком закономірно, що вчені висловлюють пропозиції щодо удосконалення терміну злочинний вплив. Наприклад, С. В. Албул під злочинним впливом у ст. 255, 255-1, 255-2 КК України пропонує розуміти будь-які умисні дії особи, спрямовані на підтримання та забезпечен- ня умов існування злочинної діяльності осіб та/чи груп осіб [26, с. 195]. У попередній публікації, яка стосувалася ще проєкту нових змін, під злочинним впливом пропонувалося розуміти будь-які діяння, спрямовані на планування, організацію, координацію, фінансування, приховування злочинної діяльності, керівництво нею, схиляння до неї чи сприяння їй, а також здійснення протиправного впливу на прийняття рішень фізичними чи юридичними особами, включаючи вирішення конфліктних ситуацій між ними [25, c. 184].

Натомість нині виходячи із законодавчого визначення, злочинний вплив характеризується двома ознаками: 1) це - дії особи, що полягають у сприянні, спонуканні, координації або здійсненні іншого впливу на злочинну діяльність, організації або безпосередньому здійсненні розподілу коштів, майна чи інших активів (доходів від них), спрямованих на забезпечення такої діяльності (зміст); 2) ці дії особа здійснює завдяки своєму авторитету, іншим особистим якостям чи можливостям (суб'єкт) [27, с. 27].

Злочинний вплив слід розглядати щонайменше у двох значеннях: широкому та вузькому. У широкому значенні його можна трактувати, приміром, як дії певних суб'єктів щодо злочинної діяльності інших осіб або ж як кримінально протиправний вплив однієї особи на іншу особу чи групу осіб. За таких обставин вчинення будь-якого злочину охоплюється злочинним впливом.

Однак у нововведених статтях злочинний вплив, очевидно, варто розуміти у вузькому - кримінальноправовому значенні. Інакше у кри- 
міналізації цього діяння не було б потреби. Скажімо вона була б навіть шкідлива, оскільки створювала б необгрунтовану конкуренцію злочинного впливу 3 певним злочиHOM.

Як свідчить практика діяльності вітчизняних правоохоронних органів, злочинний вплив полягає у таких діях, як: «коронація» у «злодії в законі»; призначення «смотрящих», «положенців»; вирішення конфліктних ситуацій між засудженими, раніше судимими та іншими особами; розподіл коштів або інших матеріальних благ між засудженими; організація та проведення зібрань в установах виконання покарань; встановлення «даху» для осіб, які вчиняють кримінальні правопорушення, злочинних об'єднань тощо. Наприклад, Особа-1 під час відбування покарання у виправній колонії, маючи попередньо здобутий серед засуджених авторитет особи, яка веде «правильний» з погляду дотримання злодійських традицій спосіб життя, був призначений «смотрящим» за зоною - виправною колонією. Це призначення відбулося з метою матеріального забезпечення та координації кримінально протиправної діяльності на території колонії, накопичення й утримання грошових коштів та іншого майна, тобто злодійського "общака», подальшого розподілу майна (у т. ч. заборонених до обігу наркотичних засобів та психотропних речовин) серед засуджених, розподілу сфер злочинного впливу. Встановлення і поширення злочинного впливу полягало у виконанні Особою-1 таких функцій:

- прийняття на території колонії усієї повноти неформальної влади;
- розроблення правил поведінки відповідно до злодійських «законів» $i$ забезпечення дотримання їх засудженими;

- призначення довірених осіб, які користуються авторитетом серед інших ув'язнених і мають значний вплив на них;

- забезпечення неухильного контролю за виконанням визначених ним правил і обов'язків засудженими в колонії шляхом встановлення покарань за невиконання таких правил $i$ обов'язків;

- забезпечення надходження та організація схеми подальшого незаконного збуту наркотичних засобів $i$ психотропних речовин на території виправної колонії;

- збирання із засуджених $i$ розподіл серед них коштів, зокрема здобутих кримінально протиправним шляхом, забезпечення наповнення «общака»;

- прийняттяя рішень про необхідність видачі ув'язненим наркотичних засобів $i$ психотропних речовин;

- забезпечення постачання на територію установи тютюнових виробів, продуктів харчування, мобільних телефонів, що розподілялись серед засуджених, які вели «правильний» у розумінні Особи-1 спосіб життя;

- ведення «бухгалтерії», в якій відображено усі надходження до злодійського «общака» - як коштів, так і продуктів харчування, тютюнових виробів, чаю, мобільних телефонів;

- визначення злочинних каст, в яких перебували засуджені, зокрема «мужиків», «козлів», а також переведення з однієї касти в іншу за вчинення дій, які виходять за межі злодійської моралі; 
- вирішення спорів, які виникали між засудженими, використовуючи неписані кримінальні закони («поняття») виступаючи в таких випадках у ролі «мирового судді» та визначаючи обгрунтованість претензій, а також приймаючи рішення про покарання винуватия;

- сприяння переведенню засуджених між локальними дільницями 3 метою здійснення певної діяльності та поширення свого злочинного впливу [27, с. 41-42].

Зазначений приклад яскраво пояснює той факт, що організовану злочинність невипадково називають п'ятою владою. Аналіз вищезазначених функцій «смотрящого» демонструє окремі ознаки законодавчої, виконавчої та судової влади на території виправної колонії.

Схожа ситуація i 3 іншими відомими національними формами організованої злочинності, наприклад 3 італійською мафією. Влітку 2019 року власника мережі з семи магазинів із продажу господарських товарів двічі обікрали. Він звернувся по допомогу до боса клану Пальяреллі. Через тиждень мафія знаходить винних та повертає викрадений товар. В інших випадках боси мафії допомагають повернути вкрадене авто, позбутися конкурентів по бізнесу, повернути борги [28].

Аналіз цих фактів свідчить, що в одних випадках злочинний вплив містить склад іншого кримінального правопорушення, а в інших ні. У зв'язку з цим виникає запитання: як кваліфікувати дії особи в таких ситуаціях? Видається, що якщо злочинний вплив не містить складу іншого кримінального правопорушення, то дії особи, яка його встановила або поширила, слід кваліфікувати за ст. 255-1 КК України. Якщо ж злочинний вплив поєднується 3 вчиненням іншого кримінального правопорушення, то дії суб'єкта злочинного впливу слід кваліфікувати за сукупністю.

3. Суспільна небезпека та безпосередні об'єкти встановлення або поширення злочинного впливу.

Суспільна небезпека цього злочину полягає в сприянні, організації та координації злочинної діяльності на певній території, підтриманні кримінально протиправних традицій, перешкоджанні виправленню засуджених, створенні альтернативи легальних органів влади, позаправовому розв'язанні спорів тощо.

Безпосереднім основним об'єктом злочину, передбаченого ст. 255-1 КК України, $є$ суспільні відносини, пов'язані з убезпеченням суспільства від злочинного впливу [27, с. 40]. Безпосереднім додатковим об'єктом цього злочину можуть бути суспільні відносини у сфері власності, правосуддя, виконання і відбування покарань тощо.

4. Об'єктивна сторона злочину, передбаченого ст. 255-1 КК України.

3 об’єктивної сторони досліджуване кримінальне правопорушення має такі форми:

1) умисне встановлення в суспільстві злочинного впливу за відсутності ознак, зазначених у ч. 5 ст. 255 КК України (це його створення, налагоджування, утвердження);

2) умисне поширення в суспільстві злочинного впливу за відсутності ознак, зазначених у ч. 5 ст. 255 КК України (це його розповсюдження, розвиток, дове- 
дення до відома інших, розширення сфери).

Відсутність ознак, зазначених у ч. 5 cm. 255 КК України.

Кримінальна відповідальність на підставі ст. 255-1 КК України може наставати за відсутності ознак, зазначених у ч. 5 ст. 255 КК України. 3 іншого боку, для інкримінування ч. 5 ст. 255 КК України слід встановити ознаки, зазначені у ст. 255-1 КК України. Неможливість одночасного притягнення до кримінальної відповідальності суб'єктів злочинного впливу за двома статтями (ст. 255 i ст. 255-1 КК України) обумовлена положенням ч. 3 ст. 2 КК, відповідно до якого ніхто не може бути притягнений до кримінальної відповідальності за одне і те саме кримінальне правопорушення більше одного разу (в нашому випадку йдеться про злочинний вплив).

Відсутність ознак, зазначених у ч. 5 ст. 255 КК України, означає, що особа, яка умисно встановлює або поширює в суспільстві злочинний вплив, не створювала злочинної організації, злочинної спільноти, не керувала злочинною організацією, її структурними частинами, злочинною спільнотою, не брала участі у злочинній організації [27, с. 44-45].

На практиці поширення злочинного впливу зазвичай кваліфікується за сукупністю кримінальних правопорушень, зокрема, з інкримінуванням при цьому ст. 129 КК України «Погроза вбивством», ст. 146 КК України «Незаконне позбавлення волі або викрадення людини», ст. 185 КК України «Крадіжка», ст. 187 КК України «Розбій», ст. 189 КК України «Вимагання», ст. 307 КК України «Незаконне виробництво, виготовлення, при- дбання, зберігання, перевезення, пересилання чи збут наркотичних засобів, психотропних речовин або їх аналогів», ст. 392 КК України «Дії, що дезорганізують роботу установи виконання покарань» [27, с. 45].

У спеціальній літературі звертається увага на те, що таке формулювання як «умисне встановлення або поширення в суспільстві злочинного впливу за відсутності ознак, зазначених у частині п'ятій статті 255 цього Кодексу» є неприпустимим для визначення об'єктивної сторони складу злочину. Законодавець повинен був уточнити, у чому проявляється «встановлення», а в чому - «поширення» злочинного впливу для забезпечення правильного розуміння та застосування вказаної норми. У цій частині положення КК України не відповідає принципам правової визначеності, ясності і недвозначності правової норми [22, с. 124].

$$
\text { Варто погодитися } 3
$$

С. Г. Киренком, що виходячи з законодавчої дефініції поняття «злочинний вплив», наданої у п. 1 примітки до ст. 255 КК України, видається зайвою вказівка в диспозиції ч. 1 ст. 2551 КК України саме на умисний характер відповідного діяння, оскільки його в принципі неможливо вчинити 3 необережності [29, с. 63-65].

\section{5. Суб'єкт злочину, передба-} ченого ст. 255-1 кК України.

Суб'єктом злочину $є$ фізична осудна особа, якій на момент вчинення злочину виповнилось 16 років.

Виникає правда питання: це загальний чи спеціальний суб'єкт злочину? Адже системне тлумачення положень ст. 255 та 255-1 КК України дає підстави стверджувати, що встановити і поширити злочинний вплив 
може насамперед особа, яка його здійснює. А якщо особа здійснює злочинний вплив, то вона має відповідати ознакам, що стосуються злочинного впливу. Слід також з'ясувати співвідношення термінів встановлення, поширення, здійснення.

Якщо особа безпосередньо не встановлює або не поширює в суспільстві злочинний вплив, однак надає допомогу у цьому іншим особам, то вона (за наявності підстав) повинна відповідати за пособництво у вчиненні злочину, передбаченого 255-1 КК України (із посиланням на ч. 5 ст. 27 КК України). Таку допомогу надають довірені особи - суб'єкти, які користуються авторитетом серед осіб, схильних до вчинення кримінальних правопорушень та злочинного способу життя, і мають значний вплив на таких осіб. Довірені особи виконують накази і розпорядження осіб, які здійснюють злочинний вплив, зокрема долають будь-який спротив правилам поведінки, встановленим «положенцем» чи «смотрящим», шляхом застосування фізичного чи психічного насильства. Водночас якщо в діях довіреної особи «положенца» чи «смотрящого» наявний злочинний вплив, то його слід визнавати виконавцем злочину, передбаченого ст. 255-1 КК України [27, с. 45].

Можливість притягнення до кримінальної відповідальності за пособництво встановленню або поширенню злочинного впливу - важливий інструмент правоохоронців. Адже досить часто такі помічники суб'єкта злочинного впливу шляхом психічного та фізичного насильства примушують певних осіб виконувати вказівки суб'єкта злочинного впливу. Наприклад, такий помічник може завдати засуджену, який не підкоря- ється кримінальному авторитету, легкі тілесні ушкодження. У такій ситуації $\epsilon$ можливість притягнути його до кримінальної відповідальності не лише за ст. 125 КК України (діяння, передбачене ч. 1 цієї статті карається штрафом до п'ятдесяти неоподатковуваних мінімумів доходів громадян або громадськими роботами на строк до двохсот годин, або виправними роботами на строк до одного року), але й за ч. 5 ст. 255-1 КК України. В описаній вище ситуації помічник суб'єкта злочинного впливу не лише завдав тілесних ушкоджень, але й примусив особу підкоритися суб'єкту злочинного впливу. Однак тут виникає декілька проблем: 1) якщо кваліфікувати вказані факти за сукупністю кримінальних правопорушень, то чи не буде тут порушено принцип non bis in idem? Видається що ні, оскільки допомога суб'єкту злочинного впливу не завжди міститиме склад іншого кримінального правопорушення (якщо міститиме - тоді сукупність); 2) чи усі види допомоги таких помічників будуть підпадати під функцію пособника. Адже допомога помічника може полягати у виконанні функцій посередника: він може передавати вказівки суб'єкта злочинного впливу потерпілому i навпаки інформацію від потерпілого суб'єкту злочинного впливу. Відтак виникає запитання: до якої функції пособника можна віднести ці дії? Такі факти наочно демонструють вади визначення пособника у ч. 5 ст. 27 КК України.

6. Кваліфікуючі та особливо кваліфікуючі ознаки встановлення або поширення злочинного впливу.

Кваліфікуючими ознаками злочину (ч. 2 ст. 255-1 КК України) $\epsilon$ 
вчинення його повторно або в ізоляторах тимчасового тримання, слідчих ізоляторах чи установах виконання покарань.

Труднощі виникатимуть 3 кваліфікацією повторності встановлення та поширення злочинного впливу. Адже, як правило, це триваючі злочини. 3 другого боку, злочинний влив може полягати в різних діях. Здебільшого це система чи комплекс дій. Відтак, очевидно, що повторність буде наявна лише у випадку рецидиву або ж вчинення нового злочину, передбаченого ст. 255-1 КК України, після того, як виявлено попередній та внесено відомості в ЄРДР.

Щодо визнання таких місць вчинення злочину як ізолятори тимчасового тримання, слідчі ізолятори чи установи виконання покарань кваліфікуючою його ознакою, виникає питання про обгрунтованість цієї обтяжуючої обставини. Адже встановлення або поширення злочинного впливу найбільш інтенсивно і дуже часто відбувається саме в таких місцях. Відтак чи $є$ потреба визнавати цю ознаку кваліфікуючою? В сучасних установах виконання та відбування покарань майже ідеальні умови для встановлення та поширення злочинного впливу. У зв'язку з цим система відбування покарань потребує удосконалення.

Особливо кваліфікуючою ознакою злочину $\epsilon$ вчинення його особою, яка перебуває у статусі суб'єкта підвищеного злочинного впливу, у т. ч. у статусі «вора в законі». Під такою особою у статтях 255, 255-1, 255-3 КК України слід розуміти особу, яка завдяки авторитету, іншим особистим якостям чи можливостям здійснює злочинний вплив і координує злочинну діяльність інших осіб, які здійснюють злочинний вплив (п. 2 примітка ст. 255 КК України).
Для
таких
суб'єктів

обов'язковим $\epsilon$ особисте здійснення злочинного впливу, а також координація злочинної діяльність інших осіб, які здійснюють злочинний вплив. Для констатації наявності статусу суб'єкта підвищеного злочинного впливу, зокрема перебування у статусі «вора в законі», необхідно встановити: 1) здійснення ним злочинного впливу; 2) здійснення злочинного впливу іншими двома чи більше суб'єктами; 3) координацію суб'єктом підвищеного злочинного впливу злочинної діяльність цих суб'єктів [27, с. 30].

Вчені неодноразово звертали увагу на вади виокремлення цих суб'єктів у кваліфікованих складах відповідних злочинів.

Насамперед виникає питання про доцільність введення поняття «вор в законі», навколо якого не вщухає дискусія й нині. Його противниками були, насамперед, фахівці Головного юридичного управління ВРУ, які у своєму висновку наголосили, що введення зазначеного поняття в кримінальне законодавство не тільки свідчить про фактичну легітимізацію злочинного жаргону, а й містить оціночне судження - «завдяки авторитету, іншим особистим якостям чи можливостям», яке можна тлумачити дуже широко. Правова невизначеність не тільки не сприятиме ефективності протидії правоохоронних органів у боротьбі 3 організованою злочинністю, а ускладнить доказування вчинення злочину злочинною спільнотою і створить підгрунтя для зловживань [30].

Крім того, незрозуміло, навіщо легітимізувати в КК України жар- 
гонні поняття тюремної субкультури. «Вор у законі» - це неформальний статус у злочинній ієрархії, він не врегульований ніякими актами та не супроводжується наданням ніякого підтверджуючого документа. Поперше, такий неформальний статус «вора в законі» може бути змінено на інший. По-друге, визнання у такий спосіб на державному рівні може призводити до його популяризації. При цьому законопроект підриває термінологічну визначеність вітчизняного кримінального права [30].

Дійсно, видається, що особливої потреби у введенні цього поняття не було, оскільки, законодавець «вора в законі» називає одним із різновидів суб'єкта підвищеного злочинного впливу. Негативним моментом введення цього поняття слід визнати i популяризацію злодійського жаргону. Водночас, з іншого боку, речі слід називати своїми іменами. Не можна виключати певний запобіжний ефект цього терміну. Ще на етапі обговорення проекту Закону України «Про внесення змін до Кримінального кодексу України щодо відповідальності за злочини, вчинені злочинною спільнотою» (№ 2513 від 02.12.2019) народний депутат В. М. В'ятрович зазначав, що «вживання кримінологічних термінів («вор в законі», «злочинна спільнота) $\epsilon, ~ з$ практичної точки зору, виправданим та має важливу превентивну мету; обумовлено існуючою наразі (пострадянською) криміногенною ситуацією і кримінальною субкультурою; забезпечує реалізацію мети законопроекту щодо посилання боротьби з організованою злочинністю [31].

Окрім цього, такий крок законодавця, можливо, навпаки сприяв дотриманню принципу правової визначності, оскільки полегшується ідентифікація певної особи як суб'єкта підвищеного злочинного впливу. Сам «вор в законі» чітко розуміє, що він відноситься до суб'єктів підвищеного злочинного впливу i без необхідності звернення за відповідними консультаціями. Його статус чітко усвідомлюють і правоохоронці, і співучасники, і потерпілі, та й взагалі будь-хто. Не було б в КК України вказівки на «вора в законі» точилися б дискусії навколо того чи підпадає він під поняття суб'єкта підвищеного злочинного впливу. Хоча, з іншого боку, поняття «вор в законі» ніде не визначено.

«Вора в законі» фактично визнано спеціальним суб'єктом злочину. Однак на відміну від більшості суб'єктів його неформальний статус нічим не врегульований, зокрема він не підтверджується жодним офіційним документом. Це, звісно, суттєво ускладнить доказування відповідних кримінальних правопорушень. Однак чи завжди статус спеціального суб'єкта можна підтвердити документально? У більшості випадків так (наприклад, якщо це працівник правоохоронного органу, то відповідно має бути наказ про його зарахування до певного органу, призначення на посаду, а також відповідне посвідчення). Однак у певних випадках ознаки спеціального суб'єкта не можуть мати документального підтвердження. Наприклад, спеціальним суб'єктом злочину, передбаченого ст. 135 КК України, може бути особа, яка поставила потерпілого в небезпечний для життя стан. В іншому випадку спеціальним суб'єктом злочину, передбаченого ст. 126-1 КК України, може бути осо- 
ба з якою потерпіла перебуває (перебувала) у близьких відносинах. Статус ні першого, ні другого спеціального суб'єкта нічим не підтверджується.

Слід враховувати те, що суб'єктом підвищеного злочинного впливу 3 погляду інкримінування ч. 5 ст. 255 КК України з урахуванням обставин справи може бути визнано і того, хто не має неформального статусу «вора в законі», «положенца» чи «смотрящего» [27, с. 36].

Відтак суб'єктом підвищеного злочинного впливу може бути «вор в законі», «положенець» та «смотрящий» за умови, що вони завдяки авторитету, іншим особистим якостям чи можливостям здійснюють злочинний вплив i координують злочинну діяльність інших осіб, які здійснюють злочинний вплив. Якщо «вор в законі» виходячи з буквального, логічного та граматичного тлумачення ч. 5 ст. 255 КК України автоматично прирівнюється до суб'єкта підвищеного злочинного впливу, то «положенець» та «смотрящий» можуть бути як суб'єктами злочинного впливу, так і суб'єктами підвищеного злочинного впливу, за умови, що вони координують злочинну діяльність інших осіб, які здійснюють злочинний вплив.

Висновки. Підбиваючи підсумки проведеного дослідження, варто сформулювати низку висновків.

1. Необхідність криміналізації злочинного впливу певною мірою обумовлена недостатньою ефективністю кримінально-правового впливу на найбільш небезпечних представників організованої злочинності - «злодіїв в законі», «смотрящих», «положенців», інших кримінальних авторитетів. Новації, пов'язані із злочинним впливом, надають можливість притягнути до відповідальності за координацію кримінально протиправної діяльності на певній території, сприяння їй, спонукання до неї.

2. Застосування поняття злочинного впливу потребує не буквального, а обмеженого тлумачення примітки 1 до ст. 255-1 КК України: під злочинним впливом слід розуміти будь-які дії особи, спрямовані на сприяння (створення умов), спонукання, координацію або здійснення іншого впливу на злочинну діяльність, організацію або безпосереднє здійснення розподілу коштів, майна чи інших активів (доходів від них), спрямованих на забезпечення такої діяльності. Вади дефініції злочинного впливу обумовлені також недоцільністю вживання термінів «завдяки авторитету, іншим особистим якостям чи можливостям» та «інший вплив на злочинну діяльність», оскільки вони порушують вимоги визначеності кримінально-правової норми.

3 огляду на зазначене, а також враховуючи необхідність усунення можливості для будь-яких спекуляцій чи потенційних зловживань під час тлумачення та подальшого застосування досліджуваної кримінально-правової заборони, визначення злочинного впливу потребує удосконалення.

3. Якщо злочинний вплив не містить складу іншого кримінального правопорушення, окрім передбаченого ст. 255-1 КК України, то дії особи, яка його встановила або поширила, слід кваліфікувати за цією статтею. Якщо ж злочинний вплив поєднується 3 вчиненням іншого кримінального правопорушення, то 
дії суб'єкта злочинного впливу слід кваліфікувати за сукупністю.

4. Суспільна небезпека цього злочину полягає в сприянні, організації та координації злочинної діяльності на певній території, підтриманні кримінально протиправних традицій, перешкоджанні виправленню засуджених, створенні альтернативи легальних органів влади, позаправовому розв'язанні спорів тощо.

5. Безпосереднім основним об'єктом злочину, передбаченого ст. 255-1 КК України, $\epsilon$ суспільні відносини, пов'язані з убезпеченням суспільства від злочинного впливу. Безпосереднім додатковим об'єктом цього злочину можуть бути суспільні відносини у сфері власності, правосуддя, виконання і відбування покарань тощо.

6. Недоцільно визнавати кваліфікуючою ознакою умисного встановлення або поширення в суспільстві злочинного впливу вчинення його в ізоляторах тимчасового тримання, слідчих ізоляторах чи установах виконання покарань, оскільки ці діяння найбільш інтенсивно і дуже часто відбуваються саме в таких місцях. Водночас, як відомо, до змісту кваліфікуючих ознак як засобу диференціації кримінальної відповідальності висувається вимога про те, що така ознака не може бути характерною для більшості випадків вчинення кримінального правопорушення.

7. Доповнення КК України положеннями про «вора в законі» має не лише недоліки, які пов'язані з легітимізацією злочинного жаргону та відсутністю однозначного визначення цього суб'єкта в законі чи теорії кримінального права, але й певні переваги - його наявність сприяє дотриманню принципу правової визначеності, оскільки полегшується ідентифікація певної особи як суб’єкта підвищеного злочинного впливу, а також має певний запобіжний ефект.

\section{Список використаних джерел}

1. Про внесення змін до Кримінального кодексу України щодо відповідальності за злочини, вчинені злочинною спільнотою: пояснювальна записка до проєкту Закону України від 2 грудня 2019 р. № 2513. URL: http://w1.c1.rada.gov.ua/pls/zweb2/ webproc4_2?pf3516=2513\&skl=10.

2. Batyrgareieva V. S., Babenko A. M., Kaija S. Corruption in medical sphere of Ukraine: current situation and ways of prevention. Wiadomości Lekarskie. 2019. T. LXXII. № 9. Cz. II. P. 1814-1821. DOI: 10.36740/WLek201909220

3. Holovkin B. M., Tavolzhanskyi O. V., Lysodyed O. V. Corruption as a cybersecurity threat in conditions of the new world's order (Корупція як загроза кібербезпеці в умовах нового світового порядку). Linguistics and Culture Review. 2021. Vol. 5, № (S3). P. 499512. https://doi.org/10.21744/lingcure.v5nS3.1538

4. Головкін Б. М. Про корупцію в приватному секторі. Часопис Київського університету права. 2020. № 4. С. 347-355. DOI: 10.36695/2219-5521.4.2020.62.

5. Дудоров О. О., Коломоєць Т. О., Кушнір С. М., Макаренков О. Л. Загальнотеоретичні, адміністративно- та кримінально-правові основи концептуалізації антикорупційної реформи в Україні: колективна монографія. Запоріжжя : Гельветика, 2019. $476 \mathrm{c}$.

6. Oksana Kvasha, Zoia Zahynei, Mykola Shapoval, Oleksii Kurylo and Viktor Nikitenko. Corruptive abuses of senior public officials in the banking sphere as a determi- 
nant of the Ukrainian economy criminalization. Banks and Bank Systems. 2019. Vol. 14 (2). P. 89-105. DOI: 10.21511/bbs.14(2).2019.08.

7. Каменський Д. В. Відповідальність за економічні злочини у Сполучених Штатах Америки та Україні: порівняльно-правове дослідження : монографія / переднє слово д-ра юрид. наук, проф. О. О. Дудорова. Київ: ВД «Дакор», 2020.1128 с.

8. Луценко Ю. В. Протидія злочинності в сучасних умовах. Соціально-правові студіï. 2020. Вип.1(7). С. 79-84. DOI: 10.32518/2617-4162-2020-1-79-84.

9. Вознюк А., Дудоров О. Кримінальна відповідальність за злочини, вчинені злочинною спільнотою: аналіз законодавчих новел. Новітні кримінально-правові дослідження - 2021: Альманах наукових праць / за ред. проф. Є.Л. Стрельцова, проф. О.В. Козаченка, PhD О.М. Мусиченко. Миколаїв: МІП НУ ОЮА, 2021. С. 21-31.

10. Кваша О. О. Корупція як складова організованої злочинності. Вісник Національної академії прокуратури України. 2017. № 4/2 (52). С. 53-58 URL: http://www.visnyknapu.gp.gov.ua/ua/arhiv-nomeriv/2017/04(2)/.

11. Бурлаков, В. Н. Понятие коррупционного соучастия и ответственность за него. Всероссийский криминологический журнал. 2020. Vol. 14(1). P. 49-58. DOI: $10.17150 / 2500-4255.2020 .14(1)$

12. Marco Di Cataldo, Nicola Mastrorocco. Organized Crime, Captured Politicians, and the Allocation of Public Resources. The Journal of Law, Economics, and Organization. 2021. ewab015. DOI: 10.1093/jleo/ewab015,

13. Finckenauer J. O., Voronin Y. A. The threat of Russian organized crime (Vol. 2). US Department of Justice, Office of Justice Programs, National Institute of Justice. 2001. $34 \mathrm{p}$. URL: https://www.ojp.gov/pdffiles1/nij/187085.pdf.

14. Батиргареєва В., Бабенко А. Вплив установ виконання покарань і попереднього ув'язнення на криміногенну ситуацію в Україні. Право Украӥни. 2020. № 2. C. 164-183. https://doi.org/10.33498/louu-2020-02-164

15. Дудоров О. О., Каменський Д. В., Титаренко С. С. Кримінально-правова оцінка зловживань державних реєстраторів у контексті протидії рейдерству. Науковий вісник Національної академії внутрішніх справ. 2021. № 1(118). С. 118-130. URL: https://scientbul.naiau.kiev.ua/index.php/scientbul/article/view/1351/1350

16. Таволжанський О. В. Кримінологічні аспекти кіберзлочинності у сучасних умовах. Журнал східноєвропейського права. 2016. № 31. С. 80-86. URL: http://dspace.nlu.edu.ua/bitstream/123456789/17724/1/Tavolzhanskyi_80-86.pdf.

17. Vozniuk A. A., Savchenko A. V., Tarasevych T. Y., Dudorov O. O., Klymenko O. A. Electronic Money and Payments as Means of Committing Crimes. Academic Journal of Interdisciplinary Studies. 2020. Vol. 9 (4). P. 150-159. DOI: https://doi.org/10.36941/ajis2020-0069

18. Varese F., Lonsky J., Podvysotskiy Y. The resilience of the Russian mafia: an empirical study. The British Journal of Criminology. 2021. Vol.61(1). P. 143-166. DOI: https://doi.org/10.1093/bjc/azaa053.

19. Dipoppa G. How Criminal Organizations Expand to Strong States: Migrant Exploitation and Political Brokerage in Northern Italy. APSA Preprints. 2021. DOI: 10.33774/apsa2021-kq3b6.

20. Нікітін А. О. «Злодій у законі» у кримінальному законодавстві: зарубіжний досвід та процес запровадження в Україні. Порівняльно-аналітичне право. 2020. № 2. C. $167-170$.

21. Юртаєва К. В., Романів Р. Р. Компаративно-критичний аналіз положень КК України щодо відповідальності за злочини, вчинені злочинною спільнотою. Вісник Асоціації кримінального права України. 2020. № 2. С. 220-232.

22. Міневич О. І. Поняття та види правових помилок: загальнотеоретичне дослідження: дис. ... канд юрид. наук: 12.00.01. Одеса, 2021. 237 с. 
23. Фріс П., Фріс I. Про боротьбу зі злочинними спільнотами (нотатки на полях закону). Юридичний вісник України. 17-30 липня 2020 р. № 28-29.

24. Речицький В. Критичний аналіз ст. 255 Кримінального кодексу України щодо встановлення відповідальності за злочини, вчинені «злочинною спільнотою» (станом на 22.07.2020). Харківська правозахисна група. Інформаційний портал «Права людини в Украӥні». 22.07.2020. URL: https://khpg.org/1595421303

25. Вознюк А. Протидія організованій злочинності в Україні: перспективи удосконалення кримінального законодавства. Вісник Пенітенціарної асоціації України. 2020. № 1 (11). C. 176-194. DOI: https://doi.org/https://doi.org/10.34015/25234552.2020.1.18

26. Албул С.В. Кримінально-правові засоби протидії злочинному впливу: світовий досвід та вітчизняні реалії. Роль та місце правоохоронних органів у розбудові демократичної правової держави: матеріали XII Міжнар. наук.-практ. інтернет-конф. (м. Одеса, 26 березня 2020 р.). Одеса: ОДУВС, 2020. С. 194-196.

27. Кримінальна відповідальність за злочини, вчинені злочинною спільнотою (статті 255, 2551, 2552, 2553, 256 Кримінального кодексу України): науковопрактичний коментар / А. А. Вознюк, О. О. Дудоров, С. С. Чернявський. Київ: Норма права, 2021. 130 с.

28. Як і чому жителі Сицилії просять мафію «вирішувати» їхні проблеми (від 8 червня 2021 p.). URL: https://www.bbc.com/ukrainian/news-57384276

29. Киренко С. Г. Проблеми кримінально-правового забезпечення боротьби 3 організованою злочинністю. Dictum factum. 2020. № 2. C. 59-65.

30. Про внесення змін до Кримінального кодексу України щодо відповідальності за злочини, вчинені злочинною спільнотою: зауваження Головного юридичного управління до проєкту Закону України від 2 грудня 2019 р. № 2513. URL: http://w1.c1.rada.gov.ua/pls/zweb2/webproc4_2?pf3516=2513\&skl=10

31. Про внесення змін до Кримінального кодексу України щодо відповідальності за злочини, вчинені злочинною спільнотою: порівняльна таблиця (друге читання) до проекту Закону України від 2 грудня 2019 р. № 2513. URL: http://w1.c1.rada.gov.ua/pls/zweb2/webproc4_2?pf3516=2513\&skl=10

\section{References}

Batyrgareieva, V. S., Babenko, A. M., \& Kaija, S. (2019). Corruption in medical sphere of Ukraine: current situation and ways of prevention. Wiadomości Lekarskie. T. LXXII. N 9. Cz. II. P. 1814-1821. DOI:10.36740/WLek201909220. URL: https://pubmed.ncbi.nlm.nih.gov/31622272/. [in English].

Holovkin, B. M., Tavolzhanskyi, O. V., \& Lysodyed, O. V. (2021). Corruption as a cybersecurity threat in conditions of the new world's order. Linguistics and Culture Review, 5(S3), 499-512. https://doi.org/10.21744/lingcure.v5nS3.1538. [in English].

Holovkin, B. M. (2020). Pro koruptsiiu v pryvatnomu sektori. Chasopys Kyivskoho universytetu prava, 4, 347-355. DOI: https://10.36695/2219-5521.4.2020.62. [in Ukrainian].

Dudorov, O. O., Kolomoiets, T. O., Kushnir, S. M., \& Makarenkov O. L. (2019). Zahalnoteoretychni, administratyvno- ta kryminalno-pravovi osnovy kontseptualizatsii antykoruptsiinoi reformy v Ukraini: kolektyvna monohrafiia. Zaporizhzhia: Helvetyka. [in Ukrainian].

Kvasha, O, Zahynei, Z., Shapoval, M., Kurylo, O., \& Nikitenko, V. (2019). Corruptive abuses of senior public officials in the banking sphere as a determinant of the Ukrainian economy criminalization. Banks and Bank Systems, 14 (2), 89-105. DOI: https://10.21511/bbs.14(2).2019.08 
Kamenskyi, D. V. (2020). Vidpovidalnist za ekonomichni zlochyny u Spoluchenykh Shtatakh Ameryky ta Ukraini: porivnialno-pravove doslidzhennia : monohrafiia / perednie slovo d-ra yuryd. nauk, prof. O.0. Dudorova. Kyiv: VD «Dakor». [in Ukrainian].

Lutsenko, Yu. V. (2020). Protydiia zlochynnosti v suchasnykh umovakh. Sotsialnopravovi studii, 1(7), 79-84. DOI: 10.32518/2617-4162-2020-1-79-84. [in Ukrainian].

Marco Di Cataldo, \& Mastrorocco, N. (2021). Organized Crime, Captured Politicians, and the Allocation of Public Resources, The Journal of Law, Economics, and Organization, ewab015. D0I: https://doi.org/10.1093/jleo/ewab015

Finckenauer, J. O., \& Voronin, Y. A. (2001). The threat of Russian organized crime (Vol. 2). US Department of Justice, Office of Justice Programs, National Institute of Justice. URL: https://www.ojp.gov/pdffiles1/nij/187085.pdf

Batyrhareieva, V., \& Babenko, A. (2020). Vplyv ustanov vykonannia pokaran i poperednoho uv'iaznennia na kryminohennu sytuatsiiu v Ukraini. Pravo Ukrainy, 2, 164183. DOI: https://doi.org/10.33498/louu-2020-02-164. [in Ukrainian].

Dudorov, O. O., Kamenskyi, D. V., \& Tytarenko, S. S. (2021). Kryminalno-pravova otsinka zlovzhyvan derzhavnykh reiestratoriv u konteksti protydii reiderstvu. Naukovyi visnyk Natsionalnoi akademii vnutrishnikh sprav, 1(118), 118-130. URL: https://scientbul.naiau.kiev.ua/index.php/scientbul/article/view/1351/1350. [in Ukrainian].

Tavolzhanskyi, O.V. (2016). Kryminolohichni aspekty kiberzlochynnosti u suchasnykh umovakh. Zhurnal skhidnoievropeiskoho prava, 31, 80-86. URL: http://dspace.nlu.edu.ua/bitstream/123456789/17724/1/Tavolzhanskyi_80-86.pdf. [in Ukrainian].

Vozniuk, A. A., Savchenko, A. V., Tarasevych, T. Y., Dudorov, O. O., \& Klymenko, O. A. (2020). Electronic Money and Payments as Means of Committing Crimes. Academic Journal of Interdisciplinary Studies, 9 (4), 150-159. DOI: https://doi.org/10.36941/ajis-2020-0069. [in Ukrainian].

Varese, F., Lonsky, J., \& Podvysotskiy, Y. (2021). The resilience of the Russian mafia: an empirical study. The British Journal of Criminology,61(1), 143-166. https://doi.org/10.1093/bjc/azaa053.

Dipoppa, G. (2021). How Criminal Organizations Expand to Strong States: Migrant Exploitation and Political Brokerage in Northern Italy. APSA Preprints. doi: 10.33774/apsa2021-kq3b6

Nikitin, A. O. (2020). «Zlodii u zakoni» u kryminalnomu zakonodavstvi: zarubizhnyi dosvid ta protses zaprovadzhennia v Ukraini. Porivnialno-analitychne pravo, 2, 167-170 [in Ukrainian].

Yurtaieva, K. V., \& Romaniv, R. R. (2020). Komparatyvno-krytychnyi analiz polozhen KK Ukrainy shchodo vidpovidalnosti za zlochyny, vchyneni zlochynnoiu spilnotoiu. Visnyk Asotsiatsii kryminalnoho prava Ukrainy, 2, 220-232. [in Ukrainian].

Minevych, O. I. (2021). Poniattia ta vydy pravovykh pomylok: zahalnoteoretychne doslidzhennia: dys. ... kand yuryd. nauk: 12.00.01. Odesa [in Ukrainian].

Fris, P., \& Fris, I. (2020). Pro borotbu zi zlochynnymy spilnotamy (notatky na poliakh zakonu). Yurydychnyi visnyk Ukrainy, 28-29 [in Ukrainian].

Rechytskyi, V. (2020). Krytychnyi analiz st. 255 Kryminalnoho kodeksu Ukrainy shchodo vstanovlennia vidpovidalnosti za zlochyny, vchyneni «zlochynnoiu spilnotoiu» (stanom na 22.07.2020). Kharkivska pravozakhysna hrupa. Informatsiinyi portal «Prava liudyny v Ukraini». URL: https://khpg.org/1595421303 [in Ukrainian].

Vozniuk, A. (2020). Protydiia orhanizovanii zlochynnosti v Ukraini: perspektyvy udoskonalennia kryminalnoho zakonodavstva. Visnyk Penitentsiarnoi asotsiatsii Ukrainy, 1(11), 176-194. DOI: https://doi.org/https://doi.org/10.34015/2523-4552.2020.1.18. [in Ukrainian].

38 | С т о ін ка 
Albul, S. V. (2020). Kryminalno-pravovi zasoby protydii zlochynnomu vplyvu: svitovyi dosvid ta vitchyzniani realii. Rol ta mistse pravookhoronnykh orhaniv u rozbudovi demokratychnoi pravovoi derzhavy: materialy XII Mizhnar. nauk.-prakt. internet-konf. Odesa: ODUVS [in Ukrainian].

Vozniuk, A. A., Dudorov, O. 0., \& Cherniavskyi S. S. (2021). Kryminalna vidpovidalnist za zlochyny, vchyneni zlochynnoiu spilnotoiu (statti 255, 255-1, 255-2, 255-3, 256 Kryminalnoho kodeksu Ukrainy): naukovo-praktychnyi komentar. Kyiv: Norma prava [in Ukrainian].

Kyrenko, S. H. (2020). Problemy kryminalno-pravovoho zabezpechennia borotby z orhanizovanoiu zlochynnistiu. Dictum factum, 2, 59-65 [in Ukrainian].

A. Vozniuk, Doctor of Law, Professor, Head of the Research Laboratory on the Problems of Combating Crime of the Educational and Research Institute No. 1 of the National Academy of Internal Affairs

ORCID: 0000-0002-3352-5626

\section{Establishment or dissemination of criminal influence: current issues of criminal liability}

The article analyzes current issues related to the criminalization of establishment or spread of criminal influence within Art. 255-1 of the Criminal Code of Ukraine. Expediency of criminalization of criminal influence is analyzed; its concept, elements and conceptual defects are revealed, social harmfulness of the crime provided in Art. 255-1 of the Criminal code of Ukraine, questions of object, objective side, subject and qualifying and especially qualifying elements of this crime are covered. Significant shortcomings that hinder effective application of Art. 255-1 of the Criminal Code of Ukraine in practice have been identified, proposals for their elimination have been provided. Recommendations on the qualification of establishing or spreading criminal influence have been formulated.

It is emphasized that innovations related to criminal influence provide an opportunity to bring to justice for the coordination of criminal activity in a particular area, its promotion, incitement to it.

It has been established that social harmfulness of this crime is to promote, organize and coordinate criminal activities in a certain area, maintain criminally illegal traditions, prevent correction of convicts, create alternatives to legal authorities, illegal dispute resolution and more.

It is argued that inclusion of the provisions on "thief in law" into the Criminal Code of Ukraine has not only shortcomings related to legitimization of criminal jargon and lack of unambiguous definition of this subject in law or theory of criminal law, but also certain advantages - its presence contributes to the principle of legal certainty, since it facilitates identification of a certain person as a subject of increased criminal influence, and also has a certain preventive effect.

Keywords: organized crime; organized group; criminal organization; criminal community; complicity; criminal activity; criminalization; criminal influence; «thief in law». 